\title{
PENGARUH KOMPENSASI TERHADAP MOTIVASI DAN KINERJA DOSEN DI UNIVERSITAS AHMAD DAHLAN
}

\author{
Suprapto \\ Universitas Ahmad Dahlan \\ e-mail : suprapto_fasnet@ yahoo.com
}

ABSTRACT

\begin{abstract}
This study aims 10 andyze the influence of funancial campensation and non-financial compensation as an independen varioble of motivation to work as an intervening variable and the performance of fas as a dependen variable. To test the hypothesis presented in this stuty we used path analysis. The restits show that direct frnancial compensation variable (X) had no significunt effect on the motwation variables (YI), while non-financial compensation rartable (X2) separately have a significant influence on the motration variables (Yl). Motivational vartables (II) directly have a significant infitute on the performance variable (Y2). Financial compensation variable (Xl) had no significam effect on the performance vartable ( $Y_{2}$ ) if it is mediated by the mothational varfables (I7). Winle non-financial compensation variable (X2) has a significam infuence on the performance variable $(Y 2)$ if it is mediated by the motwational variables $H$
\end{abstract}

Key words: financial compensation, hon-financial compensation, motivation and performance

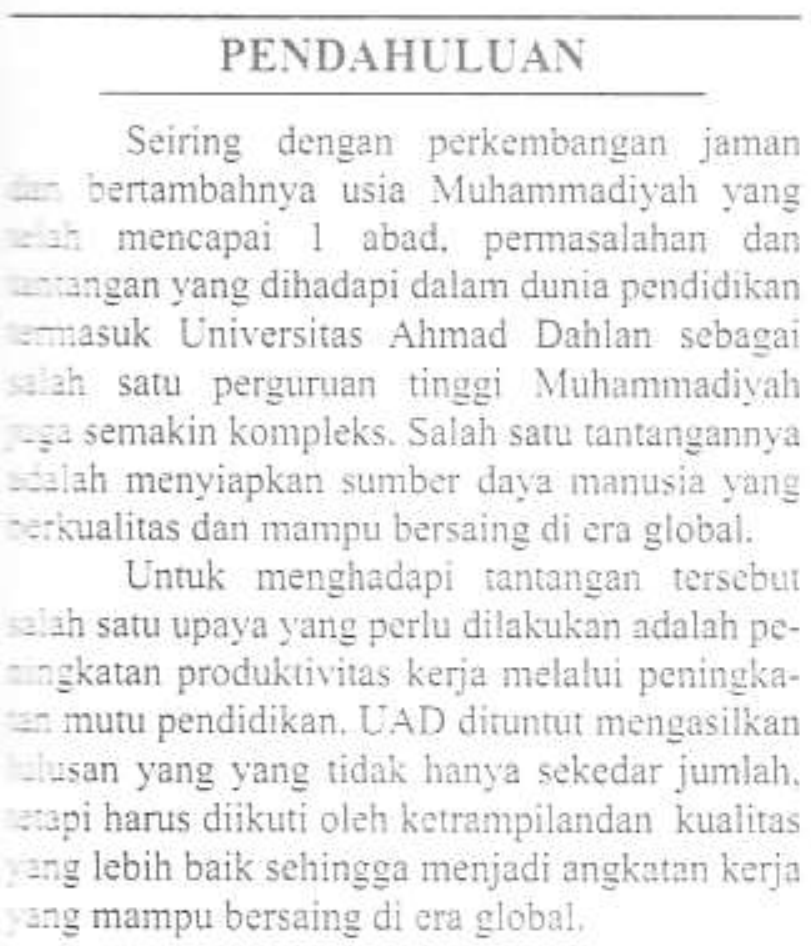

Tenaga pendidik yang profesional dapat dilihat dari kriteria: (1) kemampuan profesional. (2) upaya profesional, (3) waktu untuk kegiatan profesional dan (4) imbalan atas keria profesional (Suryadi. 2004:5). Sehingga kemampuan profesional dan upaya untuk mentrasformasikan dalam tindakan nyara disertai curahan waktu dan imbalan yang dapat menjamin hidupnya akan mampu meningkatkan kineria dosen secara maksimal.

Selain tugas pengajaran dosen juga dituntut untuk melakukan penclitian dan pengabdian pada masyarakat serta rugas lain yang diberikan oleh lembaga. Kenyataan yang di temui kinerja dosen belum maksimal. artinya belum semua dosen melaksanakan tiga tugas utama profesionalnya, sehingga pertu ada upaya peningkatan. Adanya langkah peningkatan kinerja Universitas 
Ahmad Dahlan selain didasarkan pada tuntutan realitas. juga merupakan bagian strategis dari gerakan Muhammadiyah dalan mengembangkan misi dakwah dan tajdid di bidang pendidikan. Amal usaha yang berkembang merupakan keinginan setiap individu yang berada di dalam organisasi atau lembaga tersebut, sehingga diharapkan dengan perkembangan tersebut Universitas Ahmad Dahlan mampu bersaing dan mengikuti perkembangan jaman. Perkembangan suatu perguruan tinggai dipengaruhi oleh faktor-faktor lingkungan yang bersifat intemal maupun yang bersifat ekstemai. Kinerja dosen dipengaruhi oleh bermacam-macam ciri pribadi dari masingmasing individu. Dan dalam perkembangan yang yang kompettif dan mengglobal. UAD membutuhkan dosen yang memiliki kinerja tinggi. Pada saat yang sama dosen memerlukan umpan balik atas kinerja mereka. Beberapa faktor yang menyebabkan rendahnya kinerja dosen yang disebabkan oleh tidak terpenuhinya umpan balik yang sesuai atas prestasi sehingga menyebabkan rendahnya motivasi mereka dalam bekerja yang pada akhimya berdampak pada rendahnya kinerja dosen.

Penelitian tentang pengaruh kompensasi terhadap kinerja tenaga pendidik pernah dilakukan oleh Karsono (2005). Hasil penelitian tersebut menunjukkan bahwa kompensasi berpengaruh secara signifikan terhadap kineria guru SMK teknologi dan industri di kota semarang. Namun hasil berbeda ditunjukkan oleh penelitian yang dilakukan oleh Leonard Mangunsong (2008). Hasil penelitian ini menunjukkan bahwa kompensasi memberikan sedikit kontribusi terhadap kinerja guru. artinya bila kompensasi ditingkatkan. hanya akan menaikkan sedikit kinerja guru yang bersangkutan.

Penelitian ini menarik untuk dilakukan. melihat beberapa penelitian yang menunjukkan hasil yang berbeda serta subyek penelitian ini adalah dosen yang meliliki kharakteristik berbeda dengan tenaga pendidik yang lain seperti guru.
Selain itu. penelitian ini juga bertujuan untu menguji pengaruh kompensasi terhadap motivas dan kinerja dosen pada salah satu amal usah Muhammadivah.

\section{REVIEW LITERATLR DAY HIPOTESIS}

\section{Kompensasi}

Kompensasi menjadi alasan utana mo ngapa kebanyakan orang mencari pekerjaan Bagi perusahaan atau organisasi. kompensas adalah faktor penting untuk mempertahanka karyawan dan merupakan salah satu cara untu meningkatkan motivasi karyawan sehingg mereka tetap betah berada di perusahaan ata organisasi. Kompensasi merupakan sesuaru yan: diterima karyawan sebagai pengganti kontribus jasa mereka pada perusahaan atau organisas (Rivai. 2004: 357).

Secara lebih terperinct. Rivai (2004: 35 membagi kompensasi menjadi dua kelompo yaitu kompensasi finansial dan kompensasi no finansial. Kompensasi finansial terdiri dari kon pensasi langsung dan kompensasi tidak langsun Kompensasi langsung terdiri dari pembayara karyawan dalam bentuk upah. gaji. komisi ata bonus. Kompensasi tidak langsung terdiri da semua pembayaran yang tidak tercakup dalat kompensasi langsung seperti asuransi, tunjangar tunjangan, uang lembur dan lain sebagainya. So dangkan kompensasi non finansial berupa pujiar pengakuan karya, peluang promosi dan lain seba gainya yang dapat mempengaruhi motivasi. pro duktivitas dan kepuasan kerja karyawan.

\section{Komponen - Komponen Kompensasi \\ Dalam praktiknya kompensasi yat} diberikan antara satu pemberj kerja denga pemberi kerja lainnya relatif berbeda, namu demikian menurut Rivai (2004: 360-362) secat umum komponen-komponen kompensasi yan diberikan meliputi:

1) Gaji adalah balas jasa dalam bentuk uan yang diterima karyawan sebagai konsek ensi dari kedudukannya sebagai seorar 
karyawan yang memberikan sumbangan tenaga dan pikiran dalam mencapai tujuan perusahaan. Atau dapat juga dikatakan sebagai bayaran tetap yang diterima seseorang dari keanggotaannya dalam sebuah perusahaan.

2. Upah merupakan imbalan finansial langsung yang dibayarkan kepada karyawan berdasarkan jam kerja. jumlah barang vang dihasilkan atau banyaknya pelayanan yang diberikan. Jadi tidak seperti gaji yang jumlahnya relatif tetap. besamya upah dapat berubah-ubah tergantung pada keluaran yang dihasilkan.

3) Insentif merupakan imbalan langsung yang dapat dibayarkan kepada karyawan karena kinerjanya melebihi standar yang ditentukan. Insentif merupakan bentuklain dari upah langsung diluar gaji dan upah yang merupakan kompensasi tetap yang biasa disebut kompensasi berdasarkan kinera (pay for performance plan)

4) Kompensasi Tidak Langsung (Fringe Benefit) merupakan kompensasi tambahan yang diberiakan berdasarkan kebijakan perusahaan terhadap semua karyawan sebagai upaya meningkatkan kesejahteraan para karyawan. Contohnya. berupa fasilitas-fasilitas seperti asuransiasuransi, turjangan-tunjangan, uang pensiun dan lain-lain.

\section{Tujuan Pemberian Kompensasi}

Secara umum perusahaan atau organisasi Alm memberikan kompensasi terhadap para negawai atau karyawannya memiliki tujuan sobagi berikut (Rivai. 2004;379-380):

1) Ikatan kerja sama, dengan pembetian kompensasi atau gaji upah maka terjalinlah ikatan kerjasama secara formal antara perusahaan dengan karyawan. Sehingga karyawan harus mengerjakan tugas-tugasnya dengan baik. sedangkan perusahaan perusahaan wajib membayar kompensasi atau gaji upali sesuai dengan perjanjian yang disepakati.

2) Kepuasan kerja. dengan pemberian kompensasi yang cukup karyawan dapat memenuhi kebumhan-keburuhan fisik, status sosial, dan egoistiknya sehingga memperoleh kepuasan kerja dari jabatannya.

3) Pengadaan efektif. jika program kompensasi diretapkan cukup besar, pengadaan karyawan yang qualified untuk perusahaan akan lebih mudah.

4) Motivasi, jika kompensasi atau gaji upah yang diberikan cukup besar. maka manajer akan mudah memotivasi para karyawannya.

5) Stabilitas karyawan. dengat program upah dan gaji atas prinsip adil dan layak serta eksternal konsistenst yang kompetitif maka stabilitas karyawan lebih terjamin karena turrover relatif kecil.

6) Disiplin, dengan pemberian upah dan gaji yang cukup besar maka disiplin karyawan semakin baik. mereka menyadari serta akan mentaati peraturan-peraturan yang berlaku.

7) Pengaruh serikat buruh, dengan program gaji dan upah yang baik pengaruh serikat buruh dapat dihindarkan dan karyawan akan berkonsentrasi pada pekerjaannya.

8) Pengaruh asosiasi usaha sejenis. dengan program gaji dan upah yang layak dan adil serta ekstemal konsistensi yang kompetitif maka stabilitas karyatwan lebih terjanin karena tumove? relatif kecil dan perpindahan kepertusahan sejenis dapat dihindarkan.

9) Pengaruh pemurintah. itka program gaji dan unah sestuat dengar undang-sindang peeburthun yung berlaku iseperti batas upah minimum maka intervetsi pemorintah dapat dihindarkan 


\section{Dasar Pemberian Kompensasi}

Kompensasi merupakan salah satu cara untuk mempertahankan pegawai yang telah ada dan memotivasi mereka untuk bekerja dengan sebaik-baiknva sehingga tujuan organisasi dapat dicapai dengan kinerja yang baik pula. Oleh karena itu program pemberian kompensasi harus ditetapkan atas asas adil dan layak serta memperhatikan undang-undang perburuhan yang berlaku. Prinsip adil dan layak harus mendapat perhatian yang sebaik-baiknya supaya kompensasi yang diberikan dapat merangsang gairah dan kepuasan kerja karyawan. Selain itu faktor teknis latnnya seperti ketepatan waktu pembayaran juga tidak boleh dilupakan. karena meskipun kelihatannya sepele jika pembayaran tidak tepat waktu akan menurunkan semangat atau motivasi kerja.

\section{Motivasi Kerja}

Seperti dijelaskan pada latar belakang yang mendasari penelitian ini. bahwa umumnya kinerja berkaitan dengan dua faktor utama. yairu:

1) Kesediaan atau motivasi dari pegawai untuk bekerja. yang menimbulkan usaha pegawai

2) Kemampuan pegawai untuk melaksanakannya. Dengan kata lain menurut Gomes (2003: 175). performansi atau kinerja adalah fungsi dari motivasi kerja dan kemampuan, atau $\mathrm{P}=\mathrm{f}(\mathrm{m} \times \mathrm{a})$, di mana $\mathrm{P}=$ performance, $\mathrm{m}=$ motivation, dan $\mathrm{a}=$ ability: Motivasi selalu menjadi perhatian utama dari para manajer. karena motivasi berhubungan erat dengan keberhasilan sescorang. organisasi. atau masyarakat di dalam mencapai tujuan-tujuannya.

\section{Motivasi dan Kepuasan}

Kepuasan kerja pegawai akan mempengaruhi tirgkat kehadiran pada saat bekerja dan mempengaruhi kesediaan untuk bekerja.
Kesediaan atau motivasi seorang pegawai untu bekerja biasanya ditunjukkan oleh aktivitas yan terus menerus dan selalu berorientast pada tujuar Jadiyang discburnegutraiy angbermotivasiadala pegawai yang perilakunya diarahkan kepad tujuan organsiasi dan aktivitas-uktivitasnya tida mudah terganggu oldh gangguan-gangguan kec (Gomes, 2003; 179).

\section{Faktor-Faktor Motivasi Kerja}

Motivasi seorang pekerja untuk beker biasanya merupakan hal yang rumit, karen motivasi itu melibatkan faktor-faktor individue dan faktor-faktor organisasional, Yang tergolon pada faktor-faktor yang sifatnya individu adalah kebutuhan-kebutulian (needs). tujuan tujuan (goals), sikap (attidues), dan kemampuan kemampuan (abilities). Sedangkan yang ter golong pada faktor-faktor yang berasal da organisasi meliputi pembayaran atau gaji (pay keamanan pekerjaan (job security). sesam pekerja (co-workers), pengawasan (supervision pujian (praise). dan pekerjaan iru sendiri (Gome 2003:18!).

Kinerja

Dalam suatu pernyataan Mairer bagaimana dikutip oleh Wijono (2007: 32 secara umum kinerja diartikan sebagai suat keberhasilan dari suatu individu dalam suar tugas dalam pekerjaannya. Selanjumya Porte dan Lawler dalam Wijono (2007: 32) jug menyampaikan pengertian yang hampir sam dengan menggunakan istilah prestasi kerj Mercka mengatakan prestasi kerja scbaga berikut:

"Successfil mole achievement" yan diperoleh dari hasil pekerjaan yang dikerjaka oleh individu, Atas dasar ini dapat disimpulka bahwa prestasi kerja merupakan hasil yan dicapai oleh seorang individu untuk ukuran yan telah ditetapkan dalam suatu pekerjaan. 


\section{hriteria Pengukuran Kinerja}

Kinerja setiap individu dapat diukur. namun untuk mengukur kinerja diperlukan alat - kur yang tepat. Alat ukur yang tepat belum tentu trenjadi predisi yang tepat pula jika kriteria alat - vur kinerja tersebut tidak memenuhi persyatan. Ada beberapa syarat yang harus dipenuhi mink menentukan kriteria pengukuran suatu 3. at ukur kmierja yang baik diantaranya adalah uspat dipercaya (reliable), realistis (realistic). Trewakili (representative) dan dapat meramalkan zredictable (Wijono, 2007: 34-35).

Sedangkan menurut Mairer sebagaimana cisutip oleh Wijono (2007: 35) mengatakan - Lhwa secara umum kriteria alat ukur kinerja -smpunyai beberapa aspek yaitu kuantitas dan stalitas. waktu yang dipergunakan. jabatan varg diampunya, absensi, keamanan dan keStamatan dalam melaksanakan tugas dan peserjaan. Dimensi-dimensi kinerja yang dapat -gunakan untuk mengukur kinerja antara lain meliputi: kualitas atau mutu kerja. kreativitas, anggungjawab, sikap positif. kehadiran dan ubungan dengan tim kerja.

Berdasarkan kerangka berpikir yang disumbangkan, maka hipotetis dalam penelitian ini stalah sebagai berikut:

Ha1: Kompensasi finansial mempunyai pengaruh terhadap motivasi kerja dosen di UAD.

Ha2:Kompensasi non finansial mempunyai pengaruh terhadap motivasi kerja dosen di UAD

Ha3:Motivasi kerja mempunyai pengaruh terhadap kinerja dosen di UAD.

Ha4: Kompensasi finansial dan kompensasi non finansial secara bersama-sama mempunyai pengaruh terhadap kinerja dosen dengan motivasi sebagai variabel intervening.

\section{METODE PENELITIAN \\ Populasi dan Sampel \\ Populasi dalam penelitian ini adalah semua dosen tetap swasta yayasan di Universitas Ahmad Dahlan Yogyakarta dengan masa kerja minimal 1 tahun. Merujuk pada Sekaran (2003), jumlah sampel dikatakan representatif jika jumlah sampel $30<$ Sampel Besar $<500$. Oleh karena itu pada penelitian ini jumlah sampel ditentukan sebanyak 75 sampel. Pengambilan sampel dilakukan dengan menggunakan teknik random sampling yaitu penarikan sampel secara acak untuk setiap fakultas yang ada di Universitas
Ahmad Dahlan.}

\section{Definisi Operasional dan Pengukuran
Variabel ini adalah: \\ Variabel yang digutakan dalam penelitian}

a. Independent Vartable (Variabel Bebas). teridiri atas variabel kompensasi finansial dan kompensasi non finansial. Kompensasi finansial dalam penelitian ini adalah gaji upah polok yang diberikan secara tetap kepada dosen setiap bulan dan tunjangan atau insentif uang selain gaji. Pendapat tentang baikburuknya kompensasi finansial tersebut diukur berdasarkan indikator - indikator sebagai borikut; kecukupan setiap bulannya. kesesuaian dengan risiko pekeriaan. ketepatan cara perhitungan dan ketepatan waktu pembayaran. Sedangkan kompensasi non finansial antara lain kepastian status jabatan pekerjaan, jerijong kntir. peluang promosi. pengakuan karya dan penghargatn atas prestasi istimewa. Pendapat tentang baik buruknya kompensasi non finansial tersebut diukur berdasarkan indikatorindikator sebagai berikut; kepastian status jabatum. kejelasan jenjang karir. ketepatan 
prosedur kenaikan jabatan, pengakuan karya dan penghargaan atas prestasi istimewa.

b. Dependent lariable (Variabel Terikat). berupa variable kinerja yaitu perilaku nyata yang ditampilkan setiap dosen sebagai prestasi kerja yang dihasilkan sesuai dengan perannya sebagai pengajar di perguruan tinggi atau sebagai capaian keberhasilan yang dilaksanakan dosen dalam proses mengajar. Kinerja diukur berdasarkan indikator-indikator sebagai berikut: kreativitas dalam mengajar, kerja sama dengan dosen lain. prakarsa dalam mengajar. dan tanggungjawbab dalam meiaksanakan tugas.

c. Interening Variable (Variabel Antara) Intertening variable adalah konstrak teoritis yang menjelaskan hubungan independent variable dengan dependent vartable. Intemening variable dalam penelitian ini adalah variabel motivasi. Morivasi merupakan serangkaian sikap dan nilai-nilai yang mempengaruhi dan mengarahkan setiap individu untuk mencapai hal yang spesifik sesuai dengan rujuan. Tinggi rendahnya motivasi kerja diukur dengan menggunakan indikator; kedisiplinan. perhatian / konsentrasi. kerajinan, dan pencapaian tujuan.

\section{Metode Pengumpulan Data}

Metode pengumpulan data dalam penelitian ini dilakukan dengan menggunakan angket atau kuesioner. Penyebaran kuesioner kepada responden bertujuan untuk mendapatkan data primer tentang kompensasi yang mempengaruhi motivasi dan kinerja dosen UAD. Skala pengukuran yang dipergunakan dalam penelitian ini adalah skala likert sehingga data yang diperoleh dari pengukuran skala likert adalah berbentuk data interval (Sugiyono. 2006:15).
Alat Analisis Data

Uji Validitas dan Lji Reliabilitas

Validitas diuji dengan menggunaka koefisien korelasi product momemt antara skit setiap item (butir) dengan skor total dari iten tersebut. Rumus perhitungannya adalah sebags berikut:

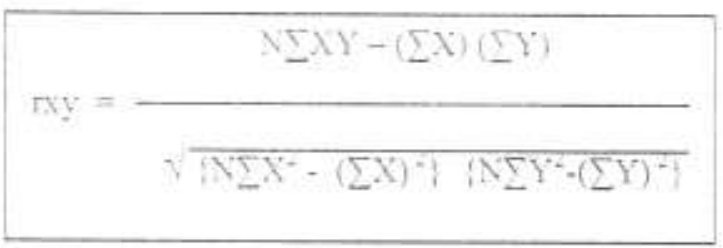

Keterangan:

$\mathrm{X}=$ nilai butir

$Y=$ nilai total butir

$\mathrm{rxy}=$ koefisien korelasi antara variabel $\mathrm{x} d a$ Variabel y

$\mathrm{N}=$ Jumlah responder

Dasar pengambilar keputusannya adala sebagat berikut:

1) Jika nilai peluang kesalahan aipha (p) 0.05 maka butir dinyarakan valid

2) Jika nilai peluang kesalahan alpha (p) 0,05 maka butir dinyatakan tidak valid Sedangkan Lji reliabilitas dilakuka dengan menggmakan teknik Alpha Cronbach Suatu instrumen dupat dikatakan handal apabil memiliki koefisien keandalan Alpha $>0,6$ ata lebih.

\section{Analisis Deskriptif}

Data primer yang berhasil dikumpulka oleh peneliti kemudian dianalisis untuk me ngetahu karakteristik responden dalam hal in dosen tetap yayasan di U.AD atau dimaksudka untuk melakuken analisis data scsuai denga klasifikasi responden dalam prosentase.

\section{Uji Asumsi Klasik}

Uji Normalitas, metode statistik yan digunakan dalam uji normalitas sebara data adalah dengan menggunakan uji no: 
parametrik tes One Sample Kolmogoro:Smirnov: Kaidah yang digunakan untuk menentukan normal tidaknya suatu sebaran data yaitu dengan menggunakan taraf signifikansi $5 \%$. Artinya jika dalam hasil analisis diperoleh nilai Kolmogorov-Smimov dengan tingkat signifikansi $>0.05$ maka residual berdistribusi normal, dan sebaliknya jika tingkat siginikansi $<=0,05$ maka residual berdistribusi tidak normal.

UjiMultikolinieritas, ujimultikolinieritas digunakan untuk mengetahui apakah antar variabel bebas saling berpengaruh atau tidak. Untuk menentukan tinggi rendahnya korelasi variabel-variabel bebas dilakukan dengan uji IarianInfiation Factor(VIF) yang mempunyai persamaan : VIF $=1$ tolerance. Artinya jika $\mathrm{VIF}>5$, maka variabel tersebut mempunyai persoalan multikolinieritas dengan variabel bebas lainnya. Sebaliknya jika VIF $\leq 5$ berarti tidak terjadi multikolinieritas antar variabel (Sugiyono. 2006).

Uji Heterokedastisitas, Metode uji heteroke-dastisitas menggunakan korelasi Sperman's tho yaitu mengkorelasikan variabel independen dengan nilai unstandardized residual. Jika korelasi antara variabel independen dengan residual diperoleh signifikansi lebih dari 0.05 maka dapat dikatakan bahwa tidak terjadi masalah heterokesdastisitas pada model regresi (Sugiyono, 2006)

\section{Analisis Inferensial}

\section{Persamaan Regresi.}

Teknik analsis data yang digunakan dalam zenelitian ini adalah model regresi nilai berganda carena variabel bebasnya terdiri dari beberapa ariabel. Persamaan regresi liner berganda dalam senelitian ini dirumuskan sebagai berikut:

1) Persamaan Regresi Tahap 1

$$
\mathrm{ZY}_{1}=\gamma_{1} \mathrm{ZX}_{1}+\gamma_{12} \mathrm{ZX}
$$

2) Persamaan Regresi Tahap 2

$$
Z Y_{2}=\beta_{2} Z X-\gamma_{2} Z X_{2}-\beta_{21} Z Y_{1}
$$

\section{Ljit}

Ujit dikenal dengan uji parsial, yaitu untuk menguji bagaimana pengaruh masing-masing variabel bebasnya secara sendiri-sendiri terhadap variabel terikatnyanya. Lji ini dapat dilakukan dengan membandingkan $t$ hitung dengan t tabel atau dengan melihat kolom signifikansi pada masing-masing thitung.

Koefisien Determinan $\left(\mathrm{R}^{2}\right)$ untuk Regresi Tahap 1 dan Regresi Tahap 2

Angka yang menunjukkan seberapa besar variabel terikat dipengaruhi oich variabel bebas. Koefisien determinan ( $\mathrm{R}$ Square) dapat diperoleh dari koefisien korelasi dikuadratkan. Untuk regresi berganda. koefien korelasi multipel dikuadratkan. Model regresi yang baik dalah model regresi yang koefisien determinannya semakin tinggi atau dengan kata lain kemampuan menjelaskan dari semua variabel bebasnya terhadap perilaku variabel terikatnya semakin tinggi. R Square biasanya dinyatakan dalam $\%$. Jadi jika nilai $100 \%$ dikurangi dengan angka $R$ Square akan diperoleh angka yang menunjukkan seberapa besar perilaku variabel terikatnya yang belum terjelaskan.

Lji F

1) Menentukan Ho: $\rho=0$

2) Mencari harga F statistik.

$$
\text { Hl: } \rho=0
$$

3) Mencart larga taraf signifikansi herdasarkan harga $F$ tersebut

4) Jika taraf signifikamsinya $>0,05$ maki Ho diterime antinya tidak ada ponganuh vang signifikan semua watiabel bebasnya secara bersama-sama terhadap variabol terikumya.

5) Sebaliknya jika harga caraf siginifikansinya < 0.05 maka $\mathrm{Hl}$ diterima artinya ada pengaruh 
yang signifikan semua variabel bebasnya secara bersama-sama terhadap variabel terikatnya.

Analisis Jalur

Analisis dilakukan dengan menggunakan korelasi dan regresi. Digunakannya analisis jalur atau pash analysis karena terdapat variabel yang berfungsi sebagai jalur antara (Y1). Tujuan dilakukannya analisis jalur untuk mengetahui apakah untuk mencapai sasaran akhir harus melewati variabel antaravariabel intervening atau bisa langsung ke sasaran akhir

HASIL PENELITIAN DAN PEMBAHASAY

Pengumpulan Data

Tabel 1

Pengumpulan Angket/Kuesioner

\begin{tabular}{|c|c|c|}
\hline No & Keterangan & Jumlah \\
\hline 1 & Kusstoner yang dischar & -5 Eksemplar \\
\hline 2 & Kuesioner vang kembuli & -5 Eksempiar \\
\hline 3 & Response Rate & $100 \%$ \\
\hline 4 & $\begin{array}{l}\text { Kuesioner sang tidak } \\
\text { kembali }\end{array}$ & 0 Eksemplar \\
\hline 5 & $\begin{array}{l}\text { Kucsionar sang tidak } \\
\text { lengkaf pengisiannya }\end{array}$ & 3 Eksemplat \\
\hline 6 & $\begin{array}{l}\text { Fotal kuestoner yang } \\
\text { lavak untuk dianalisis }\end{array}$ & Z Eksomplar \\
\hline
\end{tabular}

Sumber: hasil olali dara

\section{Uji Validitas dan Reliabilitas Instrumen}

Secara keseluruhan hasil pengujian validitas dan reliabilitas untuk setiap variabel dapat dilihat pada urain berikut :
Hasil Lji Validitas dan Reliabilitas Angket pengukur Kompensasi Finansial (X1)

Tabe1 2

Hasil Lji Validitas dan Reliabilitas Angket

Pengukur Variabel Kompensasi Finansial

(X1)

\begin{tabular}{|c|c|c|c|}
\hline Butir & Korr. Penrson & Signifikansi & Status \\
\hline $\mathrm{X}_{1}$ & 0.871 & 0.000 & Valid \\
\hline$X_{i}$ & 0.820 & 0,000 & Valid \\
\hline$X_{i}$ & 0.667 & 0.000 & Valid \\
\hline $\mathrm{X}$ & 0.583 & 0.016 & Valid \\
\hline $\mathrm{X}$ & D. $8=1$ & 0,000 & Valid \\
\hline $\mathrm{X}$. & 0,536 & 0.000 & Valid \\
\hline $\mathrm{X}$ & $00^{-5-}$ & 0.0000 & Valid \\
\hline$x$ & 0.563 & 0,000 & Valid \\
\hline $5 i 0$ & 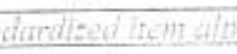 & $t=0,-25$ & Reliasci \\
\hline
\end{tabular}

Sumber hast olah don

Dari tabel di atas diketahui bahwa setiag butir mempunyai taraî signifikanisi yang besarnya $0.000<0,05$ dan besany a Stondardiseditem aiph $0.779>0.6$ dengan demikian dapat disimpulkar bahwa kuesioner pengukur variabel Kompensas: Finansial (XI) dinyatakan valid dan reliabel.

Hasil Uji Validitas dan Reliabilitas Angket pengukur Kompensasi Yon Finansial (X2)

\section{Tabel 3}

Hasil Lji Validitas dan Reifabilitas Anghet Pengukur Variabel Kompensasi Yon Finansial ( $\left.\mathrm{X}_{2}\right)$

\begin{tabular}{|c|c|c|c|}
\hline Butir & Kontr. Pearson & Signifikansi & Status \\
\hline $\mathrm{X}$ & 11556 & 0.090 & Tatid \\
\hline $\mathrm{X}$. & $0: 5=2$ & 0.600 & Tald \\
\hline$x$, & $0, \cdots 5$ & 0,000 & Valid \\
\hline$x_{3 .}$ & 0,632 & $0.0 \times n$ & Talid \\
\hline $\mathrm{X}_{7}$ & 0.741 & 0.000 & Vaind \\
\hline
\end{tabular}

Sumber; hasit stain dots 
Dari tabel di atas diketahui bahwa seap butir mempunyai taraf signifikansi yang 0 samya $0,000<0,05$ dan besarnya Standardized ie $m$ alpha $0,780>0.6$ dengan demikian dapat zisimpulkan bahwa kuesioner pengukur variabel Bompensasi Non Finansial (X2) dinyatakan valid dan reliabel.

Hasil Lji Validitas dan Reliabilitas Angket pengukur Motivasi (Y1)

Tabel 4

Hasil $\mathrm{Lji}$ Validitas dan Reliabilitas Angket Pengukur Variabel Motivasi (Y1)

\begin{tabular}{|c|c|c|c|}
\hline Butir & Korr. Pearson & Signifikansi & Status \\
\hline $\mathrm{Y}$ & 0.751 & 0.000 & Valid \\
\hline$Y:$ & 0.799 & 0.000 & Valid \\
\hline $\mathrm{Y}_{27}$ & 0.775 & 0.000 & Valid \\
\hline $\mathrm{Y}_{4}$ & 0,782 & 0.000 & Talid \\
\hline
\end{tabular}

3umber hasil olats data

Dari tabel di atas diketahui bahwa stiap butir mempunyai taraf signifikansi yang cesamya $0,000<0,05$ dan besamya Standardized alpha $0.809>0.6$ dengan demikian dapat tisimpulkan bahwa kuesioner pengukur variabel Motivasi (Y1) dinyatakan valid dan reliabel.

\section{Hasil Uji Validitas dan Reliabilitas Angket pengukur Kinerja (Y2)}

\section{Tabel 5}

Hasil Uji Validitas dan Reliabilitas Angket Pengukur Variabel Kinerja (Y2)

\begin{tabular}{|c|c|c|c|}
\hline Butir & Korr. Pearson & Signifikansi & Status \\
\hline$y_{: 1}$ & 0.695 & 0,000 & Talid \\
\hline$Y_{z}$ & 0.784 & 0.000 & Talid \\
\hline$Y_{21}$ & 0,857 & 0.000 & Talid \\
\hline$Y_{:}$ & 0.863 & 0.000 & Valid \\
\hline$Y_{:-1}$ & 0.859 & 0,000 & Valid \\
\hline \multicolumn{3}{|c|}{ Srandarined liem alpina $=11 \times 00$} & Relinhe \\
\hline
\end{tabular}

Sumber: hasil olah data
Dari tabel di atas diketahui bahwa setiap butir mempunyai taraf signifikansi yang besamya $0.000<0.05$ dan besarnya Standardizedirem alpha $0.809>0.6$ dengan demikian dapat disimpulkan bahwa kuesioner pengukur variabel Kinerja (Y 1 ) dinyatakan valid dan reliabel.

\section{Analisis Deskriptif}

Deskripsi Mengenai Variabel Kompensasi Finansial (X1)

Tabel 6

Pendapat Dosen UAD Mengenai Kompensasi Finansial

\begin{tabular}{|c|c|c|c|}
\hline SKOR & KATEGORI & F & $F\left({ }^{0} i\right)$ \\
\hline $1.0-1.8$ & Sangat Tidak & 2 & 2,50 \\
\hline$>1.8 \cdot 2.6$ & Tidak Sesua: & 21 & 29,10 \\
\hline$>2,6-3.4$ & Cukup sesuai & 26 & 36.10 \\
\hline$>3,4 \cdot 4.2$ & Sesuat & 17 & 23.60 \\
\hline \multirow[t]{2}{*}{$>4.2 \cdot 5.0$} & Sangat Sesuat & 6 & 8.40 \\
\hline & Jumlah & 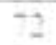 & 100.00 \\
\hline
\end{tabular}

Sumber: hasil olah dara

Dari tabel di atas dapat dijelaskan bahwa sebagian besar responden $(36.10 \%)$ menyatakan bahwa kompensasi finansial yang diterimanya sudah cukup sesuai. $23.60 \%$ menyatakan sudah sesuai dan bahkan $8.40 \%$ menyatakan sangat sesuai. Inf menunjukkan bahwa kompensasi finansial yang diberikan oleh UAD sudah cukup baik meskipun belum mencapai titik tertinggi karena masih ada yang mempersepsikan tidak sesuai sebesar $29.10 \%$ serta $2.80 \%$ responden menyatakan sangat tidak sesuai. Aminya dosen mempersepsikan bahwa kompensasi finansial yang diterimanya bisa mencukupi kebutuhan hidup setiap bulannya sudah cukup sesuai dengan resiko pekerjaannya. sudah dihitung dengan cara yang tepat dan sudah dibayarkan secara tepat waktu pula. 
Deskripsi Mengenai Kompensasi NonFinansial (X2)

Tabel 7

Pendapat Dosen UAD

Mengenai Kompensasi Non-Finansial

\begin{tabular}{|c|c|c|c|}
\hline SKOR & KATEGORI & F & $F(\%)$ \\
\hline $1.0-1.8$ & Sangat Tidak Sesuai & 0 & 0.00 \\
\hline$>1.8-2.6$ & Tidak Sesuai & 3 & 4.20 \\
\hline$>2.6 \cdot 3.4$ & Cukup sesuai & 23 & 32.00 \\
\hline$>3.4-4.2$ & Sestuti & 33 & 45,80 \\
\hline$>4.2-5.0$ & Sangat Sesuai & 13 & 18.00 \\
\hline & Jumlah & 72 & 100,00 \\
\hline
\end{tabular}

Sumber: hasil olih datu

Dari tabel di atas dapat dijelaskan bahwa sebanyak 33 dosen $(45,80 \%)$ menyatakan bahwa kompensasi non finansial yang diterimanya sudah sesuai. dan bahkan $18,00 \%$ yang lain menyatakan sangat sesuai. Hal ini menunjukkan bahwa kompensasi non finansial yang diberikan oleh UAD sudah cukup baik meskipun belum maksimal.

Deskripsi Mengenai Motivasi (Y1)

Tabel 8

Motivasi Kerja Dosen UAD

\begin{tabular}{|c|l|c|c|}
\hline SKOR & \multicolumn{1}{|c|}{ KATEGORI } & $F$ & $F\left({ }^{\circ}\right.$ e) \\
\hline $1.0-1.8$ & Sangat rendah & 0 & 0.00 \\
$>1.8-2.6$ & Rendah & 0 & 0.00 \\
$>2.6-3.4$ & Cukup & 1 & 1.40 \\
$>3.4-4.2$ & Tinggi & 42 & 58.30 \\
$>4.2-5.0$ & Sarngat Tinggi & 29 & 40.30 \\
\hline & Jumlah & 72 & 100.00 \\
\hline
\end{tabular}

Sumber hatl otati dath

Berdasarkan tabel di atas dapat dijelaskan bahwa sebanyak 42 responden $(58.30 \%$ ) menunjukkan motivasi kerja yang tinggi. dan bahkan $(40,30 \%)$ yang lain menunjukkan kinerja yang sangat tinggi. Hal ini merupakan modal yang bagus untuk terus meningkatkan kinerja dosen dalam rangka mewujudkan tujuan Universitas.
Deskripsi Mengenai Kinerja (Y2)

Tabel 9

Kineria Dosen EAD

\begin{tabular}{c|lc|c}
\hline SKOR & \multicolumn{1}{|c}{ KAIEGORI } & $F$ & $F(\%)$ \\
\hline $1.0-1.5$ & Sangat rendah & 0 & 0,00 \\
$>1.8-2.6$ & Rencah & 0 & 0.00 \\
$>2.6-3.4$ & Cukup & 6 & 8.30 \\
$>3.4-4.2$ & Tinggi & 43 & 59.70 \\
$>4.2-5.0$ & Sanga: Tinggi & 23 & 32.00 \\
\hline & Jumiah & 72 & 100.00 \\
\hline
\end{tabular}

Surtbet thasil owith date

Berdasarkan tabel di atas, sebanyak $59.70^{\circ}$ o dan $32.00^{\circ}$ o dosen memiliki kinerja tinggi dam sangal tinggi. Oleh karena itu, keadaan ini harus terus dipertahankan dan ditingkatkan dengan imbalan atau kompensast yang sesuai.

\section{Uji Asumsi Klasik}

\section{Uji Nornalitas}

Pengujian nemalitas menggunakan uji One Sample Rolmogorof-Smimor. Hasil perhitungan seperti ditunjuktan pada tabel berikut:

Tabe! 10

Hasil Uji Normalitas

\begin{tabular}{|c|c|c|c|}
\hline Variabel & $\begin{array}{c}\text { Z Kolmogorof- } \\
\text { Smirnos }\end{array}$ & Signifikansi & Keterangan \\
\hline $\mathrm{X} 1$ & 0.89 & 0.646 & Norma \\
\hline$\times 2$ & 0.9 .42 & 0,333 & Snma? \\
\hline 7 & $0,4 \equiv$ & 0.318 & Somal \\
\hline$Y 3$ & 10,979 & 0,339 & Vormal \\
\hline
\end{tabular}

Sumber hasil olah data

Hasil perhitungan menunjukkan bahwa semua variabel mempunyai taraf signifikansi > 0,05 sehingga disimpuikan astumsi nilai residual berdistribusi nomal dapat dipenuhi.

\section{Uji Multikolinearitas}

Pengujian menggunakan harga farians Infiation Facior (VIF) dengan batas maksimum 5. Berikut ini hasil perhitungan VIF untuk regres! tahap I dan II. 
Tabel 11

Harga VIF Pada Regresi tahap I dan II

\begin{tabular}{c|c|c|}
\hline Wriabel & $\begin{array}{c}\text { VIF Regresi Ta- } \\
\text { hap I }\end{array}$ & $\begin{array}{c}\text { VIF Regresi Ta- } \\
\text { hap II }\end{array}$ \\
\hline $\mathrm{X} 1$ & 1.261 & 1.289 \\
\hline $\mathrm{X} 2$ & 1.261 & 1.683 \\
\hline $\mathrm{Y} 1$ & $\ldots .$. & 1.351 \\
\hline
\end{tabular}

Sumer: hasil olah data

Dari tabel diatas disimpulkan bahwa -sik pada regresi tahap I maupun tahap II semua vanabel terbebas dari sifat multikolinearitas. sthingga asumsi terpenuhi.

\section{tji Heteroskedastisitas}

Data diasumsi tidak mempunyai sifat -atoroskedastisitas jika harga koefisien korelasi Sosaman's tho menghasilkan taraf signifikansi 0.05 . Hasil perhitungan untuk regresi tahap 1 -aupun tahap II dapat dilihat pada tabel berikut:

Tabel 12

Hasil Uji Heteroskedastisitas Pada Regresi Tahap I dan II

\begin{tabular}{c|c|c|c|c|}
\hline \multirow{2}{*}{ Variabel } & \multicolumn{2}{|c|}{ Regresi Tahap 1 } & \multicolumn{2}{c}{ Regresi tahap II } \\
\cline { 2 - 5 } & $\begin{array}{c}\text { Rank } \\
\text { Corr. } \\
\text { Spearman }\end{array}$ & Sig. & $\begin{array}{c}\text { Rank Corr. } \\
\text { Spearman }\end{array}$ & Sig. \\
\hline $\mathrm{X} 1$ & -0.013 & 0,915 & $-0,077$ & 0.519 \\
\hline $\mathrm{X} 2$ & -0.083 & 0.489 & -0.0123 & 0.545 \\
\hline $\mathrm{Y} 1$ & $\ldots . .$. & $\ldots .$. & 0.010 & 0.955 \\
\hline
\end{tabular}

Suber; hasil olati data

Tabel di atas menunjukkan bahwa semua variabel mempunyai harga koefisien korelasi Spearman's tho yang menghasilkan taraf sifnifisansi $>0.05$ artinya bahwa semua variabel tidak mempunyai sifat yang heteroskedastisitas (=homoskedastisitas) sehingga memenuhi asumsi.

\section{Analisis Jalur}

Regresi Tahap I

Pada persamaan regresi tahap I ini. variabel $X_{1}$ dan $X_{2}$ diposisikan sebagai variabel bebas dan variabel $Y$ liposisikan sebagai yariabel terikat. Dengan berdasarkan data yang telah distandardisasi dengan raitai $Z(-Z$ score), maka hasil perhitungan sccara keseluruhan seperti disajikan dalam tabel beriku int:

Tabel 13

Ringkasan Hasil Parameter Model Pada Regresi Tahup I

\begin{tabular}{|c|c|c|c|c|}
\hline $\begin{array}{c}\text { Aruif } \\
\text { Pengarula }\end{array}$ & $\begin{array}{c}\text { Rodistict } \\
\text { Itutur }\end{array}$ & T & Sig & $\mathrm{R}^{*}$ \\
\hline $\mathrm{XI} \rightarrow \mathrm{Y} 1$ & $.0 .10^{-}$ & -10.94 & 0.350 & \multirow{2}{*}{0.296} \\
\hline $\mathrm{X}_{2} \rightarrow \mathrm{Y} 1$ & 0.584 & 5.152 & 0.9000 & \\
\hline
\end{tabular}

Simters hisl olati dat

\section{Regresi Tahap II}

Pada persamaan regres than If ini, variabel X1, X2 dan Y Y1 diposisitikan sebagai variabel bebas sedang variabel $Y$ ? diposisikan sebagai variabel torikat. Dengan menggunakan data yang telah distandardisasi ke nilai $Z$. diperoleh harga-harga sebagai berikut :

Tabel 13

Ringkasan Hasil Parameter Model Pada Regresi Tahap II

\begin{tabular}{|c|c|c|c|c|}
\hline $\begin{array}{c}\text { Arah } \\
\text { Pengaruh }\end{array}$ & $\begin{array}{l}\text { Koefisien } \\
\text { Jalur }\end{array}$ & 1 & Sig & $\mathrm{R}^{2}$ \\
\hline $\begin{array}{l}\rightarrow Y^{2} \\
\rightarrow y^{2}\end{array}$ & $\frac{0.120}{011=-10}$ & $\frac{208}{108}$ & $\frac{0231}{0.575}$ & 0,475 \\
\hline
\end{tabular}

Sumber hast olah data

Hasil analisis regresi tahap I dan II tersebut di atas dapat digambarkan dalam bentuk diagram seperti berikut ini : 


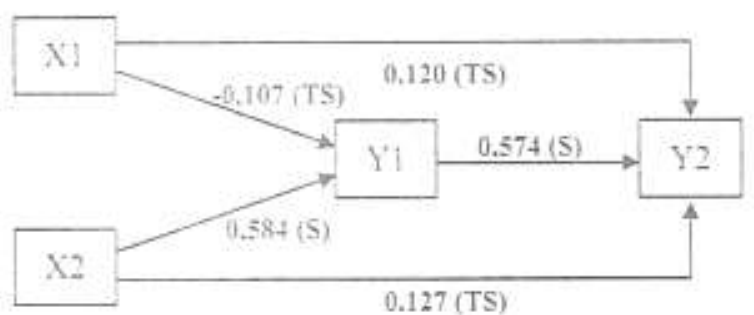

Gambar 1

Hasil Analisis Regresi Tahap I dan Tahap II

\section{Mencari Pengaruh Tidak Langsung}

Dari persamaan regresi tahap I dan tahap

II dapat dicari besarnya koefisien pengaruh secara tidak langsung, yaitu :

Tabel 14

Koefisien Pengaruh Tidak Langsung Yang Distandardisasi

\begin{tabular}{|c|c|c|}
\hline Arah Pengarth & Koutisfen Pengaruh & Keterangan \\
\hline $\mathrm{X}_{1} \rightarrow \mathrm{Y}_{1} \rightarrow \mathrm{Y}_{2}$ & $0.10^{-} \times 0.574=-0.061$ & Tidak Signifikan \\
\hline $\mathrm{X} 2 \rightarrow \mathrm{Y}_{1} \rightarrow \mathrm{Y}_{2}$ & $0.584 \times 0.574=0.335$ & Signifikan \\
\hline
\end{tabular}

Sumber: liasil olah data

\section{Mencari Koefisien Determinasi Total}

$$
R^{2}=1-\{(1-0,276)(1-0,475)\}=0,620
$$

\section{Pengaruh Langsung}

Secara langsung X1 (Kompensasi Finansial) secara terpisah tidak mempunyai pengaruh yang signifikan terhadap Y1 (Motivasi Kerja) Hal ini ditunjukkan dengan taraf signifikansi yang besarnya $0,350>0,05$. Dengan demikian hipotesis pertama yang menyatakan bahwa kompensasi finansial mempunyai pengaruh terhadap motivasi kerja dosen UAD tidak mendukung, ini berarti kompensasi finansial yang diterima para dosen tidak mampu meningkatkan motivasi kerja mereka.

Sedangkan secara langsung X2 (Kompensasi Non Finansial) secara terpisah mempunyai pengaruh terhadap YI (Motivasi Kerja).
Hal ini ditunjukkan dengan taraf signifikansi yang besarnya $0.000<0.05$. Sehingga hipotesis kedua yang menyatakan baina kompensasi non finansial mempunyai pengaruh terhadap motivasi kerja dosen LAD diterima menduktung. hal ini berari kompensasi non tinansial yang diterima para dosen mampu meningkatkan motivasi kerja mereka.

Demikian ptia dengart variabel Y1 (Motivasi Kerja) secara langsung mempunyai pengaruh terhadap Y2 (Kinerja). Hal ini ditunjukkan dengan taraf signifikansi yang besamya $0,000<0.05$. Dengan denikian hipotesis ketiga yang menyatakan bahtia bahtua motivasi kerja mempunyai pengaruh teraadap kinerja dosen UAD diterima mendukung, hal ini berarti bahwa tingginya motrasi kefja akan mampu meningkatkan kinerja dosen

Hipotesis sclanjurmy atati hipotesis ke empat yang dikembangkan dalam ponelitian ini yang meryatakan batwa kompensansi finansial dan kompensasi thon finansial secara bersamasama mempunyai pengaruh erthodap kinerja dosen UAD dengan motivasi sebagni variabe! intervening diterima mendukung Secara langsung variabel X1 dan veriabel X2 secara terpisah tidak mempunyai pengaruh terhadap Y2. Hal ini menunjukkan setiap kenaikan kompensasi, pertbahan secara langsung terhadap perbaikan kinerja tidak signifikan sehingga terkesan tidak ada perubahan kinerja

\section{Pengaruh Tidak Tidak Langsung}

Variabel Xl(Kompensasi Finansial) ternyata tidak mempunyai pengaruh yang signifikan terhadap variabel $\mathrm{Y}$ 2 (Kinerja) jika diantarai oleh variabel Yl (Motivasi Keria) dengan koefisien pengaruh sebesar -0.061 . Sedangkan variabel $\mathrm{X} 2$ (Komensasi Non Finansial) mempunyai pengaruh yang signifikan terhadap variabel $Y 2$ jika diantarai oleh variabel Y1. dengan koefisien pengaruh sebesar 0.335. Dari kedua angka koefisien pengaruh tersebut, disimpulkan bahwa 
sariabel X2 mempunyai pengaruh lebih kuat dominan) terhadap variabel $Y 2$ jika variabel Yi sebagai variabel antara dibanding dengan variabel X1. Hal ini bukan berarti mereka atau para dosen tidak memburuhkan uang, yang perlu citekankan adalah gaji yang memadai dalam suatu pekerjaan akan menentramkan mereka dan akhimya mereka terpuaskan. Senada dengan hasil genelitian Herzberg (Hasibuan, 1990:176) salah satu hal penting yang harus diperhatikan dalam memotivasi bawahan adalah pekerjaan yang menantang yang mencakup perasaan berprestasi. zertanggung jawab. kemajuan, dapat menikmati zekerjaan itu sendiri dan adanya pengakuan atas semua itu atau disebut sebagai kompensasi non tinansial.

Dosen juga merusa lebih senang dihargai atau diposisikan sebagai manusia ketimbang thargai sebagai barang atat alat produksi. Selain in terkait dengan kebutuhan religius, dosen UAD merasakan mantap dan banggga ketika dirinya ziakui sebagai bagian dari organisasi dalam hal ini Psrsyarikatan Muhammadiyah sebagai gerakan ian jalan beribadah kepada Allah SIVT untuk meraih kebahagiaan di kehidupan selanjutnya.

Jika dilihat harga koefisien determinasi votalnya sebesar 0.620 yang artinya bahwa $62 \%$ perubahan variabel Y2 disebabkan oleh perubahan variabel $X 1$ dan $X 2$ secara bersama-sama dengan sariabel Y1 sebagai variabel antara, sedangkan sisanya yang $38 \%$ disebabkan oleh variabel lain di luar model.

\section{KESIMPULAN DAN SARAN}

Berdasarkan hasil analisis data dan pembahasan penelitian tentang pengaruh kompensasi tnansial dan kompensasi non finansial terhadap motivasi dan kinerja dosen di Lniversitas Almmad Dahlan Yogyakarta, maka dapat disimpulkan sebagai berikut:

Secara langsung variabel kompensasi finansial (X1) secara terpisah tidak berpengaruh secara signifikan terhadap motivasi (Y1), sedargkin secara langsung variabel kompensasi non finansial (X2) serara terpisah mempunyai pengaruh yang signifikan tethadap motivasi (Y 1).

Variabel motivasi (Y1) secara langsung mempunyai pengarth yang signitikan terhadap variabel kinerja (Y2:

Secara langsung variabel kompensasi finansial (X1) dan variabel kompensasi non finansial( $\left.X_{2}\right)$ secara terpisah tidakmempunyai pengaruh yang signifikan terhadap variabe! kinerja ( $\left.\mathrm{Y}_{2}\right)$.

Variabel kompensasi finansial (X1) tidak mempunyai pengarul yang signifikan terhadap variabel kinerja (Y2) jika diantarai oleh variabel motivasi (Yl) dengan koeffien pengaruh sebesar -0,061.

Variabel kompensasi non finansial (X2) mempunyai pengaruh yang signifikan terhadap variabel kinerja (Y2) jika diantara: oleh variabel morivasi $Y 1$, dengan koefisien pengaruh sebesar 0.335

Variabel kompensasi non finansial ( $\mathrm{X}_{2}$ ) mempunyai pengaruh lebih kutat (dominan) terhadap variabel kinerja (Y2) jika variabel motrvasi ( $Y 1$ ) sebagai variabel antara dibanding dengan variabel kompensasi finansial (X1).

Jika dilihat harga koefisien deteminas: totalnyasebesar 0.620 yangartinya bahwa $62 \%$ pertibahan variabel kinerja ( $\mathrm{Y} 2$ ) disebabkan oleh perubahan variabel kompensasi finansial (Xi) dan variabel hompensas! non finansial (X2) secara bersama-sama dengan variabel motivasi (Yl) sebagai variabel antara. sedangkan sisanya yang $38 \%$ disebabkan oleh variubel lain di luar model.

Adapun saran yeng dapat diberikan berdasarkan hasil penelitian adalah untuk penelitian selanjutnya responden dapat dikembangkan dengan menambahkan Dosen Negeri (status 
PNS) yang diperbantukan di LAD (Dosen DPK) sehingga namtinya bisa diperoleh hasil uji beda dua kelompok yang diharapkan dapat melengkapi keterbatasan dalam penelitian ini.

\section{DAFTAR PUSTAKA \\ Arikunto, Stharsimi, 2006. Prosedur Penelitian Suani Pendekatan Praknik. Penerbit Rineka Karya. Jakarta.}

Dhamna. Surya, 2005. Alanajemen Kinerja Falsafan Teori dan Penerapannya. Pustaka Pelajar. Yogyakarta.

Gomes, Faustino Cardoso.2003. Manajemen Sumber Dava Manusia, Penerbit Andi. Yogyakarta.

Karsono 2005. Pengaruh Kompensasi Terhadap Kinerja Gum S.MK Telmologi dan Industrf. Jumal PTM Volume 5. No.1. Semarang

Kuncoro, Mudrajad. 2001, Melode Kualitatif: Teort dan Aplikasi untuk Bisnis dan Ekonomi. AMP YKPN. Edisi I.Yogyakarta.

Mahmudi. 2005. Manajemen Kinerja Sektor Publik. LPP AMP YKPN. Yogyakarta.

Mangunsong. Leonard. 2008. Pengaruh Kompensasi yang Diterima Guru dan Penilaian Guru pada Kecemasan Siswa Terhadap Kinerja Gum , http:/leoriset. blogspot.com

Manullang. 2005. Dasar-Dasar Manajemen. Gadjah Mada University Press. Yogyakarta.
Ridwan. 2005, Skala Pengukuran Variabelvariaber Penelitian. Alfabeta. Cetakan Ketiga. Bandung.

Rivai. Veithszal. 2004. . Vanajemen Sumber. Daya Mamisia wintuk Perzisahaan dari Teori ke Prakik: PT. RajaGrafindo Persada. Jakarta.

Saifudin, Azwar. 1997. Reliabiltas dan Validitas. Yogyakarta: Pustaka Pelajar. Edisi Keriga, logyakarta

Sekaran, Unua. 2006. Research, Merhods for Buriness: Metodologi Penelitian untuk Bisnis. Buku 1. Edisi 4. Salemba Empat. Jakarta

Setiaji. Bambang. 2004. Pandwan Riset dengan Pendetatan Kuantitatif. Program Pascasarjana LMS. Surakarta.

Siagian, Sondang P. 1995. Teari Motivasi dan Aplikasinya. PT Rineka Cipta. Cetakan Kedua. Jakarta.

Sugiyono. 2006. Hetode Penelitian Bisnis. Penerbit Alfabeta. Cetakan Kesembilan. Bandung.

Trihendradi. Comelius. 2004. Memecahkan Kasus Statistik: Deskriptif. Paramerik dan Non Parametrik dengen SPSS 12. Penerbit Andi. Yogyakarta.

Umar. Husein. 2001. Riset Akuntansi, PT Gramedia Pustaka Utama. Jakarta

Wijono. Sutarto. Motivasi Kerja.Widya Sari. Salatiga. 2007. 